\title{
Effect of Coat Characteristics on Physiological Traits and Heat Tolerance of West African Dwarf Sheep in Southern Nigeria
}

\author{
M. I. Okourwa \\ Department of Animal Science, Ambrose Alli University, Ekpoma, Nigeria \\ Email: odionokos@yahoo.com, okosmich@gmail.com
}

Received 30 July 2015; accepted 20 September 2015; published 23 September 2015

Copyright (C) 2015 by author and Scientific Research Publishing Inc.

This work is licensed under the Creative Commons Attribution International License (CC BY).

http://creativecommons.org/licenses/by/4.0/

(c) (i) Open Access

\section{Abstract}

This experiment was conducted to investigate the effect of coat characteristics on physiological traits and heat tolerance of dwarf sheep in southern Nigeria. A total number of twenty West African dwarf male sheep with an average weight of $9.00 \pm 0.52 \mathrm{~kg}$ and aged 10 months old were used for the experiment. The dwarf sheep were assigned to four treatment groups in a completely randomized design with five sheep per treatment group. The compared treatment groups were $T_{A}$ (black coat colour sheep with low coat depth and short hair length), $T_{B}$ (black coat colour sheep with high coat depth and long hair length), $T_{C}$ (light brown coat colour sheep with low coat depth and short hair length) and $T_{D}$ (light brown coat colour sheep with high coat depth and long hair length). The results obtained in the study showed that midday was significantly $(P<0.05)$ highest in ambient temperature $\left(31.00^{\circ} \mathrm{C}\right)$ and temperature humidity index (28.94), but relative humidity was insignificantly $(P>0.05)$ affected by morning, midday and evening. Rectal temperature $\left(40.09^{\circ} \mathrm{C}\right)$, respiratory rate $(21.01$ breaths $/ \mathrm{min})$, pulse rate $(87.49 \mathrm{beats} / \mathrm{min})$, heat tolerance coefficient $(97.10 \%)$, haemoglobin $(9.04 \mathrm{~g} / \mathrm{l})$, blood cell $\left(10.84 \times 10^{6} / \mu \mathrm{l}\right)$, white blood cell $(12.06 \times$ $\left.10^{6} / \mu \mathrm{l}\right)$ and glucose $(50.10 \mathrm{mg} / \mathrm{dl})$ were significantly $(\mathrm{P}<0.05)$ highest in $T_{C}$ while packed cell volume (PCV) $(30.08 \%)$ was best in $T_{D}$. Significant difference $(P>0.05)$ did not occur in total protein, albumin and globulin among treatment groups. It is concluded that coat characteristics have significant effects on physiological indices and heat tolerance in Nigeria.

\section{Keywords}

Coat Characteristics, Physiological Traits, Heat Tolerance, Sheep 


\section{Introduction}

Small ruminants in Nigeria are integral component of the rural household, where they contribute to the food, and cultural and socio-economic life of the people. Numerous scientific reports [1] [2] indicate that sheep and goats are the principle domesticated small ruminants in terms of total numbers and food productivity in Nigeria. These attributes of sheep and goats may partly be due to their small body size and easy management system when compared with cattle. The potential of sheep production in southern Nigeria has not been fully explored by livestock farmers. This is due to the shortage of good quality feeds needed to sustain livestock growth and harsh climatic factors that constitute stressful condition to the management of animals [3].

However, the exposure of sheep to high environmental temperature and relative humidity with prolonged direct sunlight induce heat-stress, which is known to adversely affect animal production in the humid tropics. Heat-stress occurs when physiological mechanism of an animal fails to negate the excessive heat load [4] which results in increase in rectal temperature that invokes numerous of physiological changes in animals. Helal et al. [5] note that heat stress has been generally associated with detrimental effects on physiological equilibrium of animals and that various systems have been implicated with specific responses and reciprocal regulatory influences. Furthermore, environmental heat radiation has been found by [6] as an important influential of body temperature and heat tolerance. Thus, evaluation of heat tolerance has been carried out, using physiological adaptation tests involving respiratory rate, heart rate, body temperature and individual heat tolerance coefficient [6]-[8]. However, blood system is particularly sensitive to changes in environmental temperature, being another important indicator of physiological response to stressing agent in animals. Al-Haidary [6] reported that physiological responses and heat tolerance superiority of animals to environmental stress showed that heat stress had profound effects on blood profile. Thus, the maintenance of body temperature within the physiological limits is necessary for sheep to remain healthy, survive and maintain its productivity.

Nevertheless, coat is the first defence layer protecting animals from direct sunlight and this protection differs according to many factors like coat colour, coat depth and hair length. Sheep coat is highly repeated character with heritability estimate that is used as possible indicators of genetic superiority or production adaptability. Although [9] found that coat colour type had significant effects on heat stress in dwarf sheep, there was still paucity of information regarding the effect of coat characteristics on physiological traits and heat tolerance of dwarf sheep. Therefore, this study has been designed and conducted with the aim of exploring the effect of coat characteristics on physiological traits and heat tolerance of dwarf sheep in southern Nigeria.

\section{Materials and Methods}

Description of Study Area: The study was carried out during the dry season (between December and February) at the Small Ruminant Unit of the Teaching and Research Farm, Ambrose Alli University, Ekpoma. The livestock Farm lies between long. $6.09^{\circ} \mathrm{E}$ and lat. $6.42^{\circ} \mathrm{N}$ in Esan West local Government Area of Edo State, Nigeria. Ekpoma is within the southern geo-political zone of Nigeria and has a prevailing tropical climate with mean annual rainfall and ambient temperature of about $1556 \mathrm{~mm}$ and $31^{\circ} \mathrm{C}$ respectively. The vegetation represents an interface between the tropical rainforest and the derived savannah.

Experimental Animals and Their Management: A total number of twenty growing West African dwarf male sheep of different coat characteristics were sourced from villages and markets located at Irrua and Ekpoma in Edo State. The experimental dwarf sheep (ram lambs) were between 9 and 10 months of age with an average body weight of $9.00 \pm 0.53 \mathrm{~kg}$ at the commencement of the study. The dwarf sheep were divided into four treatment groups (A, B, C and D) with five sheep per treatment group in a completely randomized design. Treatment A consisted of 5 sheep of black coat colour, low coat depth and short hair length. Treatment B comprised 5 sheep of black coat colour, high coat depth and long hair length. Treatment $C$, constituted 5 sheep of light brown coat colour, high coat depth and short hair length. While treatment $\mathrm{D}$ made up of 5 sheep of light brown coat colour, high coat depth and long hair length. The sheep were healthy and clinically free of external and internal parasites. They were kept maintained and treated in adherence to accept standards for the human treatment of animals. They were housed in demarcated individual pens with open pasture land. The sheep were opened from their pens and allowed to graze on pasture land as from $8.00 \mathrm{am}$ in the morning to $6.00 \mathrm{pm}$ in the evening daily throughout the study period to enable them receive much of the solar radiation. Concentrate supplementary (wheat offal $80 \%$, brewery dried grain $18 \%$, oyster shell $1 \%$, salt $1 \%$ ) at a level of $2.5 \%$ body weight was offered twice daily (morning and evening). The proximate composition of the concentrate (DM 85\%, CP 
$20.78 \%$, EE $1.06 \%$, CF $15.00 \%$ and ash $9.02 \%$ ) was determined according to [10]. The sheep also have free access to clean fresh water throughout the study and the total duration of the experiment was 84 days.

Experimental Procedure: The coat depth and hair length of the dwarf sheep were sampled from six body positions. Three dorsal (withers, back and rump) and three laterals (shoulder, mid-side and Britches), which were measured using a ruler and recorded as the distance between the skin surface and the coat surface as reported by [5]. Low and high coat depth was ranged between 4 to $5 \mathrm{~cm}$ and 6 to $7 \mathrm{~cm}$ respectively, while short and long hair length were ranged between 3 to $4 \mathrm{~cm}$ and 5 to $6 \mathrm{~cm}$ respectively.

Ambient temperature $\left(\mathrm{AT}^{\circ} \mathrm{C}\right)$ and relative humidity $(\mathrm{RH} \%)$ were measured three times daily (morning, afternoon and evening) using a thermometer and barometer respectively throughout the study. Temperature humidity index (THI) was calculated using the following equation: $\mathrm{THI}=\mathrm{DBT}-\{(0.31-0.31 \times \mathrm{RH})(\mathrm{DBT}-14.4)\}$ where DBT $=$ dry bulb temperature $\left({ }^{\circ} \mathrm{C}\right)$ and $\mathrm{RH}=\mathrm{RH} \% / 100$ as reported by [11] [12].

Rectal temperature $(\mathrm{Tr})$, respiratory rate $(\mathrm{Rr})$ and heart rate $(\mathrm{Hr})$ in dwarf sheep were also measured three times daily. Rectal temperature was measured using digital thermometer. Respiratory rate was determined by counting the number of abdominal movement per minute. Pulse rate was recorded by placing the finger tips on the femoral arteries of the hind limb for one minute and read from the stopwatch. Heat tolerance coefficient (HTC) was calculated using the following equation:

$\operatorname{HTC}(\%)=100-10\left(\right.$ average $T_{\mathrm{r}}$ after exposure - normal control $\left.\mathrm{T}_{\mathrm{r}}\right)$ as reported by [6].

Two set of blood were also collected from each animal by jugular venipuncture using sterile disposable $10 \mathrm{ml}$ needles of 20 gauge and syringes. A set of the blood samples $(5 \mathrm{ml})$ were transferred immediately into plastic tubes containing the anti-coagulant ethylene diamine tetra-acetic acid (EDTA) for haematological study [13]. Another set of $5 \mathrm{ml}$ blood samples were placed into sterile tubes without anti-coagulant for serum biochemical study as reported by [5].

Statistical Analysis: Data collected from the study were analysed using the general liner model (GLM) procedure for repeated measurement analysis of variance (ANOVA) using the software program of statistical analysis system [14]. Statistical means were compared using Duncan Multiple Range Test (DMRT).

\section{Results and Discussion}

The climatic data that prevailed during the study is shown in Table 1. Ambient temperature (AT) and temperature humidity index $(\mathrm{THI})$ were significantly $(\mathrm{P}<0.05)$ higher in the midday $\left(31.00^{\circ} \mathrm{C}\right.$ and $\left.28.84^{\circ} \mathrm{C}\right)$ compared to morning $\left(22.07^{\circ} \mathrm{C}\right.$ and $\left.21.16^{\circ} \mathrm{C}\right)$ and evening $\left(22.56^{\circ} \mathrm{C}\right.$ and $\left.21.58^{\circ} \mathrm{C}\right)$. Relative humidity $(\mathrm{RH})$ was insignificantly $(\mathrm{P}>0.05)$ affected, although midday value $(60.00 \%)$ was lower than morning $(61.64 \%)$ and evening $(61.23 \%)$. However, the higher AT recorded in the midday was higher than the critical temperature of $24^{\circ} \mathrm{C}$ to $27^{\circ} \mathrm{C}$ for most animal species [5]. Temperature humidity index (THI) values below 22.2 are normally considered as acceptable (absence of heat stress), less than 23.3 are moderate heat stress, while those less than 25.6 are severe heat stress but those above 25.6 are considered as severe to extreme heat stress [12] [6]. Therefore, the obtained climactic data during this study indicated that studied dwarf sheep were under comfortable environmental conditions in the morning and evening but were exposed to heat stress during the midday.

Presented in Table 2 are thermoregulatory parameters and heat tolerance coefficient of dwarf sheep as affected by coat characteristics? Rectal temperature values of $40.09^{\circ} \mathrm{C}, 39.26^{\circ} \mathrm{C}, 38.96^{\circ} \mathrm{C}$ and $38.29^{\circ} \mathrm{C}$ were obtained for $T_{A}, T_{B}, T_{C}$ and $T_{D}$ respectively. This revealed that rectal temperature was significantly $(P<0.05)$ highest in sheep with black coat colour, low coat depth and short hair length $\left(\mathrm{T}_{\mathrm{A}}\right)$ and lowest in sheep with light brown coat colour, high coat depth and long hair length $\left(\mathrm{T}_{\mathrm{D}}\right)$. This implies that the highest rectal temperature observed for $\mathrm{T}_{\mathrm{A}}$ was due to the absorption of solar radiation by the dark pigmentation, low coat depth and short

Table 1. Climatic data prevailed during the experimental period.

\begin{tabular}{ccccc}
\hline Climatic parameters & \multicolumn{3}{c}{ Time } & Evening \\
\cline { 2 - 5 } & Morning & Midday & $22.56^{\mathrm{b}}$ & 0.62 \\
\hline Ambient temperature $\left({ }^{\circ} \mathrm{C}\right)$ & $22.07^{\mathrm{b}}$ & $31.00^{\mathrm{a}}$ & 61.23 & 1.23 \\
Relative humidity $(\%)$ & 61.64 & 60.00 & $21.58^{\mathrm{b}}$ & 0.49 \\
Temperature humidity index & $21.16^{\mathrm{a}}$ & $28.94^{\mathrm{a}}$ & \\
\hline
\end{tabular}

\footnotetext{
${ }^{\mathrm{a}, \mathrm{b}}$ Mean within the same row with different superscripts differ significantly $(\mathrm{P}<0.05)$. SEM $=$ Standard error of mean.
} 
hair length that could not help the sheep to protect itself especially from direct sunlight. Unlike sheep on $T_{D}$ that had light pigmentation, high coat depth and long hair length to reflect more solar radiation, absorbs less solar radiation into the body. This explanation was in harmony with the result found by [15] who reported that light colour hair coats that are sleek and shiny reflects a greater proportion of incidents solar radiation than hair coats that are dark in colour and more dense or woolly. In addition, [5] also confirm in their findings that thermal insulation by coat increased with increasing coat depth and attributed to the air space between the hair fibres. However, the rectal temperature values observed in this study was within the reported value $\left(39.00^{\circ} \mathrm{C}\right)$ of sheep to remain within the narrow limits of stress, if its welfare is to be safe guarded and production maintained at acceptable levels [9]. Respiratory rate that ranged from 14.98 to 21.01 breaths per minute was significantly $(\mathrm{P}<$ $0.05)$ affected by coat characteristics. The respiratory rate followed the same pattern of variation as observed with rectal temperature. Alamer and Al-Hozab [16] reported that respiration rate can be used as an indicator of stress and to estimate the adverse effects of environmental temperature. Furthermore, [6] suggested that respiration rate was practical and reliable measure of heat load and stated that respiration rate above 20 breaths per minute for sheep is an indication of stress. However, the observed difference in respiratory rate in this study was as a result of sheep panting in order to increase body cooling by respiratory evaporation, since panting is the major evaporator heat mechanism and respiratory frequencies that tend to follow closely the heat loss by evaporation [4]. Coat characteristics also had significant $(\mathrm{P}<0.05)$ effect on pulse rate with sheep in black coat colour $\mathrm{T}_{\mathrm{A}}(87.49$ beats $/ \mathrm{min})$ and $\mathrm{T}_{\mathrm{B}}(87.00$ beats $/ \mathrm{min})$ recorded the highest estimated beats per minute for pulse rate than the sheep with light brown coat colour $\mathrm{T}_{\mathrm{C}}(79.00$ beats $/ \mathrm{min})$ and $\mathrm{T}_{\mathrm{D}}(78.36$ beats $/ \mathrm{min})$. The observed accelerated pulse rate in sheep with black coat colour could probably due to highest rectal temperature and respiratory rate associated with the sheep which could exceeds the comfort zone, thereby resulting in redistribution of blood to peripheral tissue during heat exposure [11]. This finding supported the previous reports on sheep and goats [12] [17].

Heat tolerance coefficient values of $80.90 \%, 87.40 \%, 90.40 \%$ and $97.10 \%$ that were recorded for $\mathrm{T}_{\mathrm{A}}, \mathrm{T}_{\mathrm{B}}, \mathrm{T}_{\mathrm{C}}$ and $T_{D}$ respectively, was significantly $(P<0.05)$ affected by coat characteristics of dwarf sheep. Sheep with light brown colour, high coat depth and long hair length $\left(\mathrm{T}_{\mathrm{D}}\right)$ proved to be the best heat tolerant dwarf sheep while sheep with black coat colour, low coat depth and short hair length $\left(\mathrm{T}_{\mathrm{A}}\right)$ were the least. The above result of $\mathrm{T}_{\mathrm{D}}$ was referred to be the best in heat tolerance as a result of low recorded rectal temperature of the sheep. This corresponds with the findings of [17] who reported that the degree of rectal temperature in ruminant animal play an important role in heat tolerance of the animal. Thus, it is noteworthy that the adaptation capacity to harsh environment can be evaluated using rectal temperature, respiratory rate, pulse rate and heat tolerance, where average relative deviation from normal due to exposure to hot climate in thermal parameters of the sheep could be used in the estimation of adaptability to a hot climate [4].

Table 3 shows the effect of coat characteristics on haematological and serum biochemical indices of dwarf sheep. Packed cell volume $(\mathrm{PCV})$ was significantly $(\mathrm{P}<0.05)$ influenced by coat characteristics of the dwarf sheep. The percentage increased in PCV was highest in light brown coat colour sheep $\mathrm{T}_{\mathrm{C}}(29.99 \%)$ and $\mathrm{T}_{\mathrm{D}}$ (30.08\%) than black coat colour sheep $\mathrm{T}_{\mathrm{B}}(27.54 \%)$ and $\mathrm{T}_{\mathrm{A}}(25.92 \%)$. However, higher PCV values have been reported to be an adaptive mechanism of desert animals to provide the necessary water required for evaporative cooling process [11]. The PCV values recorded in this study were higher than the ranged of values $(24.83 \%$ to $25.75 \%)$ reported by other workers [9] [3] for dwarf sheep and goats. Haemoglobin $(\mathrm{Hb})$ concentration values were significantly $(\mathrm{P}<0.05)$ higher in black coat colour sheep $\mathrm{T}_{\mathrm{A}}(9.04 \mathrm{~g} / \mathrm{l})$ and $\mathrm{T}_{\mathrm{B}}(8.98 \mathrm{~g} / \mathrm{l})$ compared to light brown coat colour sheep $\mathrm{T}_{\mathrm{C}}(7.69 \mathrm{~g} / \mathrm{l})$ and $\mathrm{T}_{\mathrm{D}}(7.34 \mathrm{~g} / \mathrm{l})$. Difference in coat characteristics of the dwarf sheep

Table 2. Thermoregulatory parameters and heat tolerance coefficient of dwarf sheep as affected by coat characteristics.

\begin{tabular}{|c|c|c|c|c|c|}
\hline \multirow{2}{*}{ Parameters } & \multicolumn{4}{|c|}{ Treatments } & \multirow{2}{*}{$\mathrm{SEM} \pm$} \\
\hline & $\mathrm{T}_{\mathrm{A}}$ & $\mathrm{T}_{\mathrm{B}}$ & $\mathrm{T}_{\mathrm{C}}$ & $\mathrm{T}_{\mathrm{D}}$ & \\
\hline Rectal temperature $\left({ }^{\circ} \mathrm{C}\right)$ & $40.09^{\mathrm{a}}$ & $39.26^{\mathrm{b}}$ & $38.96^{\mathrm{c}}$ & $38.29^{c}$ & 0.09 \\
\hline Respiratory rate (breaths/min) & $21.01^{\mathrm{a}}$ & $19.84^{\mathrm{b}}$ & $15.02^{\mathrm{c}}$ & $14.98^{c}$ & 0.05 \\
\hline Pulse rate (beats/min) & $87.49^{\mathrm{a}}$ & $87.00^{\mathrm{a}}$ & $79.00^{\mathrm{b}}$ & $73.36^{\mathrm{c}}$ & 1.02 \\
\hline Heat tolerance coefficient $(\%)$ & $80.90^{\mathrm{d}}$ & $87.40^{\mathrm{c}}$ & $90.40^{\mathrm{b}}$ & $97.10^{\mathrm{a}}$ & 1.04 \\
\hline
\end{tabular}

a, b, c, d Mean within the same row with different superscripts differ significantly $(\mathrm{P}<0.05)$. SEM $=$ Standard error of mean. 
Table 3. Effects of coat characteristics on haematological and serum biochemical indices of dwarf sheep.

\begin{tabular}{|c|c|c|c|c|c|}
\hline \multirow{2}{*}{ Parameters } & \multicolumn{4}{|c|}{ Treatments } & \multirow{2}{*}{$\mathrm{SEM} \pm$} \\
\hline & $\mathrm{T}_{\mathrm{A}}$ & $\mathrm{T}_{\mathrm{B}}$ & $\mathrm{T}_{\mathrm{c}}$ & $\mathrm{T}_{\mathrm{D}}$ & \\
\hline $\operatorname{PCV}(\%)$ & $25.92^{\mathrm{c}}$ & $27.54^{\mathrm{b}}$ & $29.99^{\mathrm{a}}$ & $30.08^{\mathrm{a}}$ & 0.21 \\
\hline $\mathrm{H}_{\mathrm{b}}(\mathrm{g} / \mathrm{dl})$ & $9.04^{\mathrm{a}}$ & $8.98^{\mathrm{a}}$ & $7.69^{\mathrm{b}}$ & $7.34^{\mathrm{b}}$ & 0.10 \\
\hline $\operatorname{RBC}\left(\times 10^{6} / \mu \mathrm{l}\right)$ & $10.84^{\mathrm{a}}$ & $9.01^{\mathrm{b}}$ & $7.01^{\mathrm{c}}$ & $6.98^{\mathrm{c}}$ & 0.06 \\
\hline $\operatorname{WBC}\left(\times 10^{6} / \mu \mathrm{l}\right)$ & $12.06^{\mathrm{a}}$ & $11.72^{\mathrm{b}}$ & $9.89^{\mathrm{c}}$ & $9.24^{\mathrm{c}}$ & 0.09 \\
\hline \multicolumn{6}{|c|}{ Serum biochemical parameters } \\
\hline Total protein $(\mathrm{g} / \mathrm{dl})$ & 4.82 & 4.87 & 4.92 & 4.99 & 0.07 \\
\hline Albumin $(\mathrm{g} / \mathrm{dl})$ & 2.98 & 3.00 & 3.13 & 3.18 & 0.03 \\
\hline Globulin $(\mathrm{g} / \mathrm{dl})$ & 1.84 & 1.87 & 1.79 & 1.81 & 0.05 \\
\hline Cholesterol (mg/dl) & $39.16^{\mathrm{c}}$ & $40.03^{\mathrm{c}}$ & $62.00^{\mathrm{a}}$ & $59.06^{\mathrm{b}}$ & 1.32 \\
\hline Glucose (mg/dl) & $50.10^{\mathrm{a}}$ & $47.72^{\mathrm{b}}$ & $30.21^{\mathrm{c}}$ & $31.01^{\mathrm{c}}$ & 1.24 \\
\hline
\end{tabular}

\footnotetext{
${ }_{\mathrm{a}, \mathrm{b}, \mathrm{c}}$ Mean within the same row with different superscripts differ significantly $(\mathrm{P}<0.05)$. SEM $=$ Standard error of mean.
}

could be the possible explanation of this variation in $\mathrm{Hb}$ concentration values, thus showed that the vital physiological relationship of $\mathrm{Hb}$ with oxygen in the transport of gases (oxygen and carbon dioxide) to and from the tissue of the body has not been maintained in the dwarf sheep. Red blood cell (RBC) values of 10.84, 9.01, 7.01 and $6.98 \times 10^{6} / \mu$ were recorded for $\mathrm{T}_{A}, \mathrm{~T}_{\mathrm{B}}, \mathrm{T}_{\mathrm{C}}$ and $\mathrm{T}_{\mathrm{D}}$ respectively. Black coat colour sheep with low coat depth and short hair length $\left(\mathrm{T}_{\mathrm{A}}\right)$ was significantly $(\mathrm{P}<0.05)$ highest, followed by black coat colour sheep with high coat depth and long hair length $\left(T_{B}\right)$ before light brown coat colour sheep $T_{C}$ and $T_{D}$. The higher $R B C$ values recorded in $\mathrm{T}_{\mathrm{A}}$ and $\mathrm{T}_{\mathrm{B}}$ could be attributed to high heat burden on black coat colour which brought physiological need for increase in haemoglobin to cope with oxygen circulation during panting of heat stressed sheep. This observation is in conformity with the findings of [9]. Who reported that black coat colour increased heat stress and red blood cell count in dwarf sheep? White blood (WBC) was also significantly $(\mathrm{P}<0.05)$ affected by the coat characteristics. The black coat colour sheep with low coat depth and short hair length $\left(\mathrm{T}_{\mathrm{A}} 12.06 \times 10^{6} / \mu \mathrm{l}\right)$ had the highest value of WBC while light brown coat colour sheep with high coat depth and long hair length $\left(\mathrm{T}_{\mathrm{D}}\right.$ $\left.9.24 \times 10^{6} / \mu \mathrm{l}\right)$ had the least. The WBC value of black coat colour sheep with high coat depth and long hair length $\left(\mathrm{T}_{\mathrm{B}} 11.72 \times 10^{6} / \mu \mathrm{l}\right)$ was significantly $(\mathrm{P}<0.05)$ higher than brown coat colour sheep with low coat depth and short hair length $\left(\mathrm{T}_{\mathrm{C}} 9.89 \times 10^{6} / \mu \mathrm{l}\right)$. These variations in $\mathrm{WBC}$ count could be the effects of rectal temperature and immunologically challenged of the studied dwarf sheep that attributed to physiological adjustment that presented against negative antigenic effect. Similar observation was reported by [3] who observed significant lower WBC count in studied dwarf goats of high rectal temperature.

Serum biochemical parameters are important in the proper maintenance of the osmotic pressure between the circulating fluid and the fluid in the tissue so that the exchange of materials between the blood and cells could be facilitated. They also contributed to the viscosity and maintenance of the normal blood pressure and the physiological states of animals [18]. Total protein, albumin and globulin that ranged from 4.82 to $4.99 \mathrm{~g} / \mathrm{dl}, 2.98$ to $3.18 \mathrm{~g} / \mathrm{dl}$ and 1.79 to $1.87 \mathrm{~g} / \mathrm{dl}$ respectively, were not significantly $(\mathrm{P}>0.05)$ affected by coat characteristics. The general low values obtained in total protein, albumin and globulin could be due to heat shock and increase in blood volume to maintain both homoeothermic peripheral vasodilatation and sweating which subsequently caused low in plasma proteins concentration in serum [5]. Cholesterol value of 39.16, 40.03, 59.06 and 62.00 $\mathrm{mg} / \mathrm{dl}$ were recorded for $\mathrm{T}_{\mathrm{A}}, \mathrm{T}_{\mathrm{B}}, \mathrm{T}_{\mathrm{C}}$ and $\mathrm{T}_{\mathrm{D}}$ respectively. Light brown coat colour sheep with high depth coat and long hair length $\left(\mathrm{T}_{C}\right)$ were significantly $(\mathrm{P}<0.05)$ highest while black coat colour sheep $\left(\mathrm{T}_{\mathrm{A}}\right.$ and $\left.\mathrm{T}_{\mathrm{B}}\right)$ were the lowest. The marked decreased in cholesterol concentration in black colour sheep could probably due to the decrease in their acetate concentration which is the primary precursor for the synthesis of cholesterol. This is in consistence with the reports of [5] who reported that acetate concentration and coat characteristics have significant effect on physiology of goat breeds. Glucose had opposite trend with the cholesterol values in the treatment groups. The black coat colour sheep $\mathrm{T}_{\mathrm{A}}(50.10 \mathrm{mg} / \mathrm{dl})$ and $\mathrm{T}_{\mathrm{B}}(47.72 \mathrm{mg} / \mathrm{dl})$ were significantly $(\mathrm{P}<0.05)$ higher compared with the light brown coat colour sheep $\mathrm{T}_{\mathrm{C}}(30.21 \mathrm{mg} / \mathrm{dl})$ and $\mathrm{T}_{\mathrm{D}}(31.01 \mathrm{mg} / \mathrm{dl})$. Helal et al. [5] demonstrated that the increase in plasma glucose concentration during hot condition may be due to the decrease in 
glucose utilization, depress of both catabolic and anabolic enzymes secretion and subsequent reduction of metabolic rate.

\section{Conclusions}

Coat characteristics are very important for the adaptability of sheep to hot climatic condition. They also support, predict and forecast the potentiality and productivity of sheep to harsh tropical environmental condition.

However, the results of this study indicate that light brown coat colour dwarf sheep are less susceptible to physiological challenges and more tolerant to heat under hot environmental condition prevailing in southern Nigeria. This was more pronounced in light brown coat colour dwarf sheep with high coat depth and long hair length $\left(\mathrm{T}_{\mathrm{D}}\right)$.

The black coat colour dwarf sheep with low coat depth and short hair length $\left(\mathrm{T}_{\mathrm{A}}\right)$ had confirmed some extent of susceptibility to physiological stress and less tolerance to heat. Hence, dwarf sheep under such conditions would require environmental modification in the midday to alleviate the impact of such stress.

\section{References}

[1] Odeyinka, S.M. and Ajaja, D.A. (2004) A Survey of Feedstuffs for Goats in Osun State. Tropical Journal of Animal Science, 7, 161-168.

[2] Ozung, P.O., Nsa, E.E., Ebegbulem, V.N. and Ubua, J.A. (2011) The Potentials of Small Ruminant Production in Cross-River Rain Forest Zone of Nigeria: A Review. Continental Journal of Animal and Veterinary Research, 3, 3337.

[3] Okoruwa, M.I., Adewumi, M.K. and Igene, F.U. (2013) Thermophysiological Responses of West African Dwarf (WAD) Bucks Fed Pennisetum purpureum and Unripe Plantain Peels. Nigerian Journal of Animal Science, 15, 168178.

[4] Marai, I.F.M., El-Darawany, A.A., Fadiel, A. and Abdel-Hafez, M.A.M. (2007) Physiological Traits as Affected by Heat Stress in Sheep: A Review. Small Ruminant Research, 71, 1-12. http://dx.doi.org/10.1016/j.smallrumres.2006.10.003

[5] Helal, A., Hashem, A.L.S., Abdel-Fattah, M.S. and El-Shaer, H.M. (2010) Effect of Heat Stress on Coat Characteristics and Physiological Responses of Balady and Damascus Goats in Sinai, Egypt. American-Eurasian Journal of Agricultural \& Environmental Science, 7, 60-69.

[6] Al-Haidary, A.A., Samara, E.M., Okab, A.B. and Abodun, K.A. (2013) Thermophysiological Responses and Heat Tolerance of Saudi Camel Breeds. International Journal of Chemical, Environmental\& Biochemical Science, 1, 173-176.

[7] Charoensook, R., Gatphayak, K., Sharifi, A.R., Chaisongkram Brenig B. and Knorr, C. (2012) Polymorphisms in the Bovine HSP90ABI Gene Are Associated with Heat Tolerance in Thai indigenous Cattle. Tropical Animal Health and Production, 44, 921-928. http://dx.doi.org/10.1007/s11250-011-9989-8

[8] Castanheira, M., Paiva, S.R., Louvandini, H., Landim, A., Fiorvanti, M.C.S., Dallago, B.S., Correa, P.S. and McManus, C. (2010) Use of Heat Tolerance Traits in Discriminating between Groups of Sheep in Central Brazil. Tropical Animal Health and Production, 42, 1821-1828. http://dx.doi.org/10.1007/s11250-010-9643-x

[9] Sanusi, A.O., Peter, S.O., Sonibare, A.O. and Ozojie, M.O. (2010) Effect of Coat Colour on Heat Stress among West African Dwarf Sheep. Nigerian Journal of Animal Production, 38, 28-36.

[10] AOAC (1995) Official Methods of Analysis. 14th Edition, Association of Official Analytical Chemists, Washington DC, 141 .

[11] Al-Haidary, A.A., Aljumaah, R.S., Alshaikh, M.A., Abdoun, K.A., Samara, E.M., Okab, A.B. and Alfuraiji, M.M. (2012) Thermoregulatory and Physiological Responses of Najdi Sheep Exposed to Environmental Heat Load Prevailing in Saudi Arabia. Pakistan Veterinary Journal, 32, 515-519.

[12] Marai, I.F.M., El-Darawany, A.A., Abou-Fandoud, E.I. and Abdel-Hafez, M.A.M. (2009) Reproductive and Physiological Traits of Egyptian Suffolk Rams as Affected by Selenium Dietary Supplementation during the Sub-Tropical Environment of Egypt. Archive Tierzucht, 52, 402-409.

[13] Ikhimioya, I. and Imasuen, J.A. (2007) Blood Profile of West African Dwarf Goats Fed Panicum maximum Supplemented with Afzelia aficana and Newbouldia laevis. Pakistan Journal of Nutrition, 5, 79-84.

[14] SAS (2003) Statistical Analysis System User's Guide: Statistical Version 8 Edition. SAS Institute, Cary.

[15] Hansen, P.J. (2004) Physiological and Cellular Adaptation of Zebu Cattle to Thermal Stress. Animal Reproduction Science, 82, 349-360. http://dx.doi.org/10.1016/j.anireprosci.2004.04.011 
[16] Alamer, A. and Al-Hazah, A. (2004) Effect of Water Deprivation and Season of Feed Intake, Body Weight and Thermoregulation in Awassi and Najdi Sheep Breeds in Saudi Arabia. Journal of Arid Environments, 59, 71-84. http://dx.doi.org/10.1016/j.jaridenv.2004.01.003

[17] Mc-Manus, C., Prescott, E., Paludo, G.R., Bianchini, E., Louvandini, H. and Mariante, A.S. (2009) Heat Tolerance in Naturalized Brazilian Cattle Breeds. Livestock Science, 120, 256-264. http://dx.doi.org/10.1016/j.livsci.2008.07.014

[18] Ocak, S., Darcan, N., Cankaya, S. and Inal, T.C. (2009) Physiological and Biochemical Responses in German Fawn Kids Subjected to Cooling Treatments under Mediterranean Climate Condition. Turkish Journal of Veterinary and Animal Sciences, 33, 455-461. 